\title{
An Approach to Geotopes of Jajrud Catchment Basin from Meygun to Darbandsar
}

\section{ASEMEH SOLEIMANIFAKHR ${ }^{1}$ and KAMRAN REZAEIZADEH MAHABADI*}

\author{
'Department of Geography, Faculty of Literature, Central Tehran Branch, \\ Islamic Azad University, Tehran, Iran. \\ ${ }^{2}$ Department of Geography, Faculty of Science, Shahr-e-Rey Branch, \\ Islamic Azad University, Tehran, Iran.
}

http://dx.doi.org/10.12944/CWE.9.2.33

(Received: June 03, 2014; Accepted: July 14, 2014)

\begin{abstract}
Development of urbanization imposed many mental and physical stresses on citizens. Air Pollution, noise pollution, Overcrowding, cars and the lack of green space caused Urbanites to need to have more leisure time. These causes resulted in interests of authorities to tourism. Tourism plays an important role in both Increasing revenues and employment and cultural and social aspects. Geotopes and geological phenomenon including caves, canyons, valleys, fossil sites, beaches etc., as a geological heritage, can be examined as potential geosites in developing geotourism and establishing geoparks. The studied area has various Climatic and geomorphological heritage including glacial cirques, terrace, wandering rocks, canyons and cliffs, caves and springs reflecting the ancient climates. Hence, it can be introduced as a platform for more geographical research as a geosite.
\end{abstract}

Key words: Geotope, Geosite, Geotourism, Geopark.

\section{INTRODUCTION}

Tourism is the main factor for sustainable development in the economic, social, cultural and environmental levels (Papoli Yazdi \& Saqaei, 2006). Recently, tourism industry has found a wide approach to ecotourism. By its inherent objectives, that is environment protection, commitment to local communities and respect for cultural characteristics of the host community, Ecotourism is a plan option with most consistency with the concept of sustainable development (Ghazi \& Ghadiri, 2011).

Iran is considerably capable of tourism development. In terms of latitude and climate variability, there are various geotopes under Natural conditions of Iran which can play as an important role in tourist attraction and tourism development (Hamedi \& Rezvani, 2012).
Geotourism, as an interdisciplinary subject, deals with all tourism infrastructures including management, accommodation and tours. Unlike ecotourism which deals with animate attractions, geotourism generally addresses inanimate nature attractions (Nekoui Sadri, 2009).

In the studied area, located in southern Alborz Mountains, the climate is favourable for attracting tourists. The mountainous landscape of the region and the Jajrood River, Shemshak and Dizin ski resort and Hamloon Cave can be a factor in attracting tourists to the area.

Besides these factors, the existence of climatic and geomorphological heritage is also suitable for studies of geologists and geographers. 


\section{Problem Statement}

Geotourism is a branch of tourism as a new term recently used in tourism campaign of countries. Wherever one goes is on the earth, every part of the earth has its geological unique attractions, referring to the tourism based on geologic resources (Zandi, 2010).

Geotopes or geological phenomena are effective factors on Geotourism development and establishment of geoparks (Wikipedia). These areas, mostly interested by geotourists, are scientifically important; so that, ecologists and those interested in natural history are attracted to geotopes (Nojavan, et al., 2009).

The studied area has many different geotopic areas. Glacier cirques, moraines, river terraces and fossil straw indicate climatic variations of different geological periods.

Glacial cirques are of great importance in environmental and paleoclimatic studies, because the height of the outlet opening of cirques represents an annual temperature of zero degrees. With respect to the above, it can be concluded that glacial cirques, wandering rocks and morins created a situation where the environment can be considered as a paleo climate geotope in paleontology studies. Lack of scientific resources in relation to this phenomenon is a critical problem in planning and development in the tourism sector (Nojavan, et al., 2009). Despite the various tourist attractions and high capability to attract tourists, there is no study and planning for using these areas and providing facilities for tourism development can be important from different aspects.

\section{The Importance and Necessity of Research}

Geotourism is a nature-related tourism dealing with introducing the geology phenomena to tourists. Audience of geotourism are not only experts, but also ordinary tourists interested in the nature (Abedi, 2012).

By diverse geology, climate, geologic features, there are various geotopes such as caves, beaches, and Kalut in Iran, which can be used as geological heritage in the form of potential geosites following provision of tourism infrastructures as a tool to work towards the establishment of geoparks and geotourism development (Wikipedia).

Due to the high altitude of the region, the snow remains longer on slopes. Mountain glaciers in the form of snow filed maintain snow until midsummer. Hence, it can play a critical role in providing fresh water.

The studied area is capable of tourist activities; it also can be used as a Laboratory for studies of geology and geomorphology students.

\section{Hypotheses}

It seems that the studied area is highly capable of tourist attraction and tourism and geotourism development in terms of ecology and geomorphology as well as favourable climatic conditions.

\section{Literature Review \\ Definitions}

Geotourism is one of the newest approaches to recognize geology and identify natural capital of any area using Earth Sciences, geomorphology, geology and other natural sciences (Maleki Orsi \& Najaf Zadeh, 2012).

Geotope refers to the area including natural heritage which reflects the history and development of the region (Nojavan, et al., 2009).

Geosite refers to a place with a rare and valuable geological or geomorphological phenomenon. These sites should be scientifically and aesthetically valuable and the possibility of visiting should be available publicly (Zandi, 2010).

Geopark refers to lands with unique geological phenomena and evolutionary history of geology. In fact, "geopark" is an area where geological heritage are well and sustainably conserved and managed. In other words, geopark is a territory of one important site, or more, in scientific (not just geological, but also archaeological, ecological or cultural) terms (Salimian, 2007).

\section{Background}

Geotourism is a new term in tourism, introduced for the first time in Iran by Nabavi (1999). 
Afterwards, major works conducted on Iranian geotourism include studies of Kazemi (2002, 2004, and 2006).

Kamyabi (2008) evaluated the natural and geotourism attractions of Hablehrud basin and National Park of Semnan Desert. He suggested that the area had the ability to become a geopark through development planning and optimal utilization of geotourist systems.

Using the term, geomorphotourism and geotourism, Zomorrodian (2005) and Servati (2006)

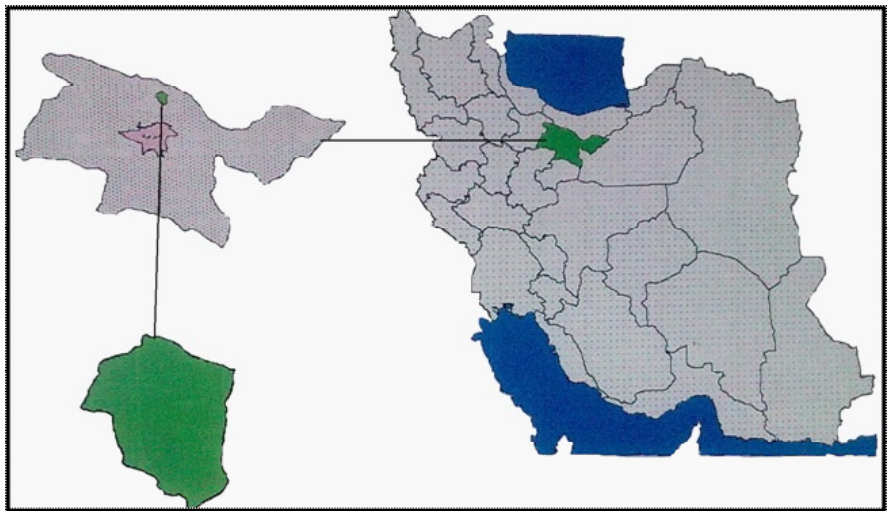

Fig. 1: Geographic location of the studied area

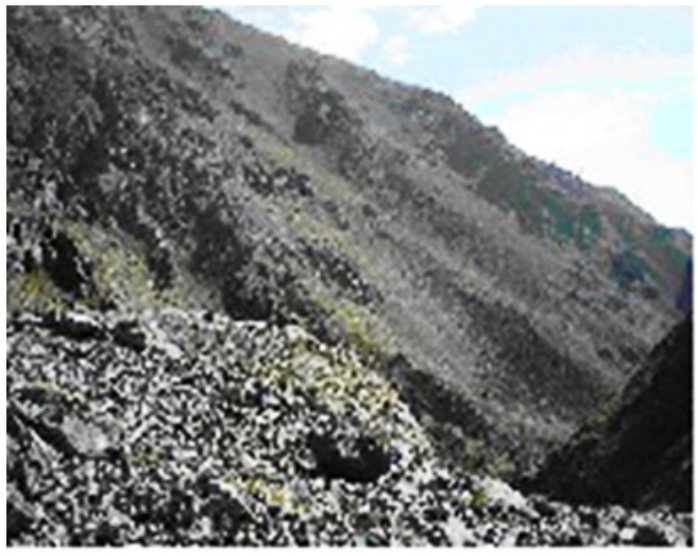

Fig. 2: glacial cirque and terrace; photo by author, 2008 studied the north coast of the Caspian Sea and Hamadan, respectively.

Articles are also written in this field.Nojavan and colleagues (2009) considered geotopes of Yazd as potential for development of tourism and geotourism.Taheri and Moradnejad (2010) introduced the glacial alpine environments of Ashtarankooh as a geosite.Studying fossil geosite of Maragheh, Safari Paskeh (2001) studied variety of fossils and places where they were discovered as a fossil site.Ghazi and Ghadiri evaluated geotourist capabilities of National Desert Park using new strategic planning model and SWOT to provide solutions for geotourism management. In the first

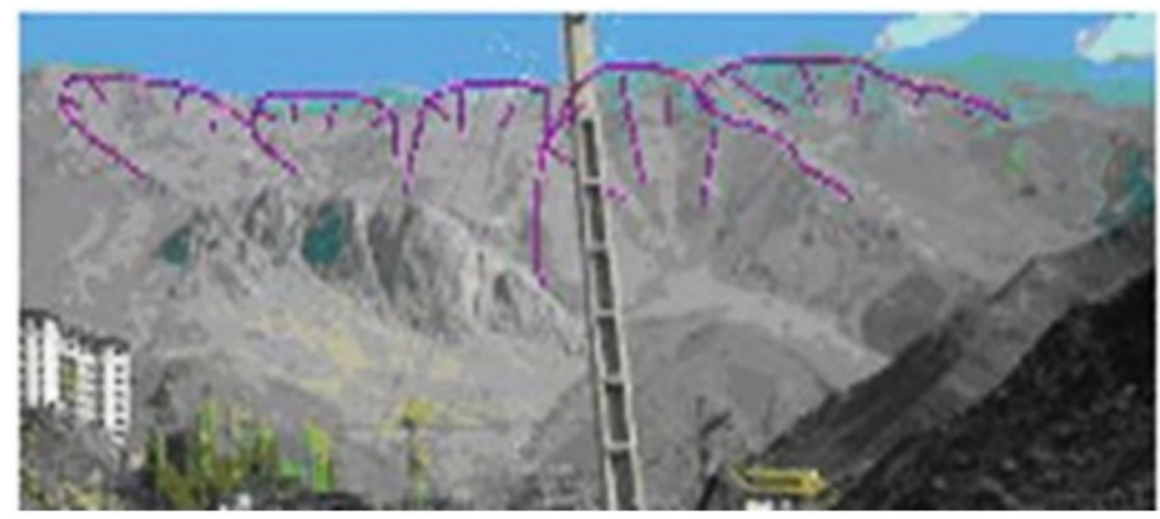

Fig. 3: glacial cirques near Shemshak; photo by author, 2008 
conference of Geological Heritage of Iran, Shah Amiri Tabatabai and Ghassemi (2012) introduced Tang-Tikab geosite and Devon village, Kazeron, as one of the tourist attractions in the Fars province. Maleki Orsi and colleagues (2012) introduced the Aras Geo Park and Uch Tepe geosite.

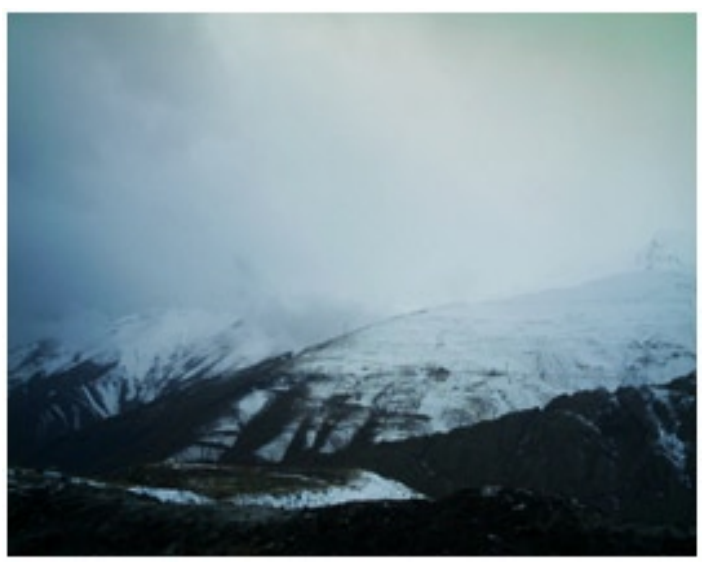

Fig. 4: gradual melting of the snow; photo by author, 2008

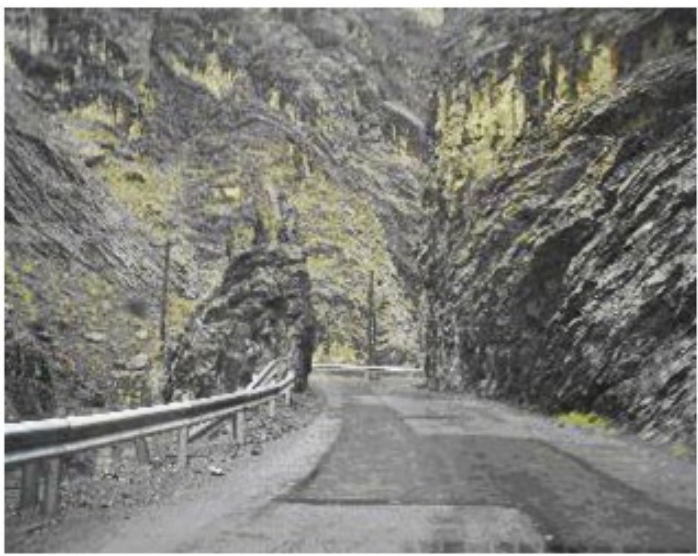

Fig. 5: The physical erosion, the limestone Hamloon; photo by author, 2008

\section{The Studied Area}

The Studied Area is a part of Central Alborz in $51^{\circ} 35^{\prime}$ and $51^{\circ} 25^{\prime}$ east longitude and $36^{\circ} 5^{\prime}$ and $35^{\circ} 55^{\prime}$ north latitude located in the north of Tehran (Figure 1). The area is limited from north to Koloon Bastak Mountain (4124 meters) and Khortunak

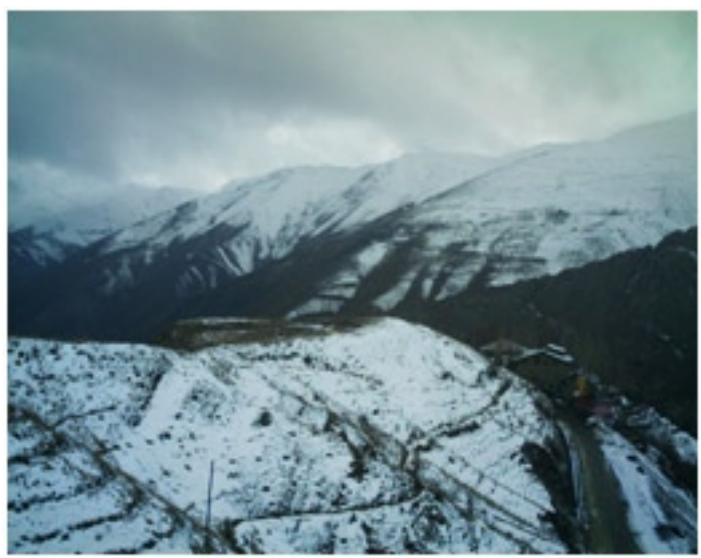

Mountain (4156 m), from east to Garmabedar Basin, from west to Dizin Basin, and from south to Meygun. The highest point of the area is 4156 meters and the lowest point is 2200 meters. The study area is 58 square kilometers.

The climate of this region can be used to explain the causes of ancient glacial conditions. Therefore, evaluation of the glacial forms can be conducted by analysis of climatic elements.

In glacial periods (initial Quaternary), the studied area was also affected by ice conditions. Glacial conditions are more or less similar to the erosion of the southern slopes of Alborz, which can be verified through geomorphological evidence. In

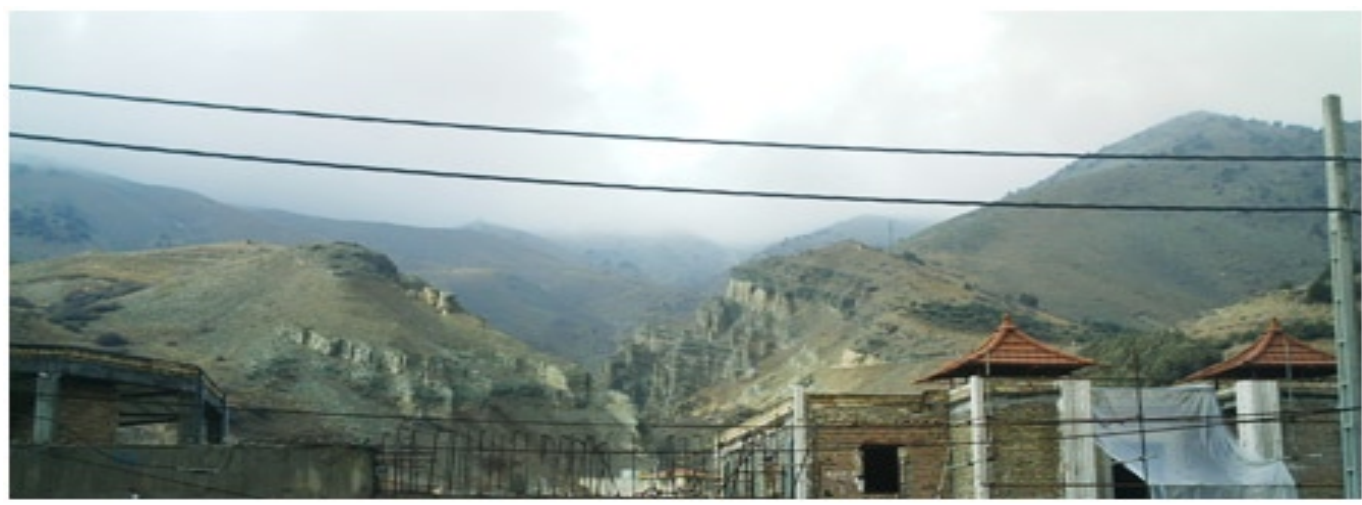

Fig. 6: rocky walls; photo by author, 2008 
glacial periods, morphology of the area formed under climate and local topography at different levels under influence of dominant erosion processes such as glacial erosion. Following climatic conditions and warming, the upper limit of erosion domains was mostly Ascending. Due to the reduced height of the mountains, glacial erosion was substituted by other morphoclimatic conditions. This has happened several times intermittently in this area.

To identify the effects of glacial erosion, studies have been carried out on 1:50000 and 1:250000 topographic maps and field studies. Existence of cirques and glacial valleys with glacial deposits in the northern part of the area indicate glacial conditions (Figure 2,3). Sometimes there are big rocks on the riverbed which do not appear to have the ability to move by water

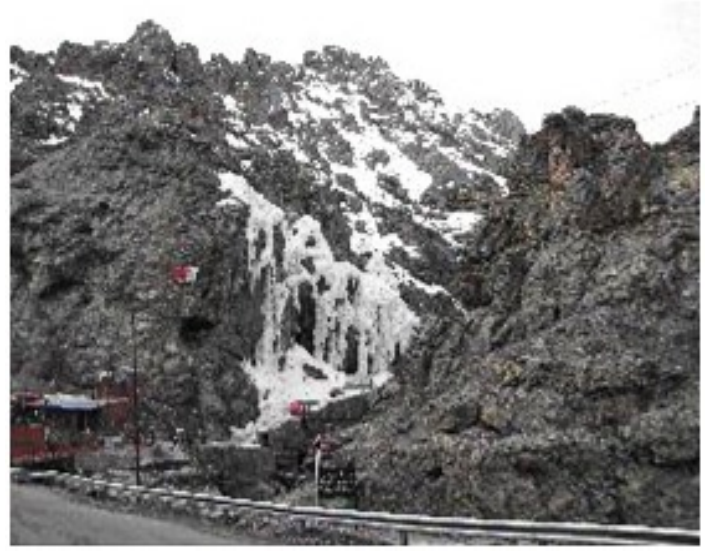

Fig. 7: entrance of Hamloon valley; photo by author, 2008

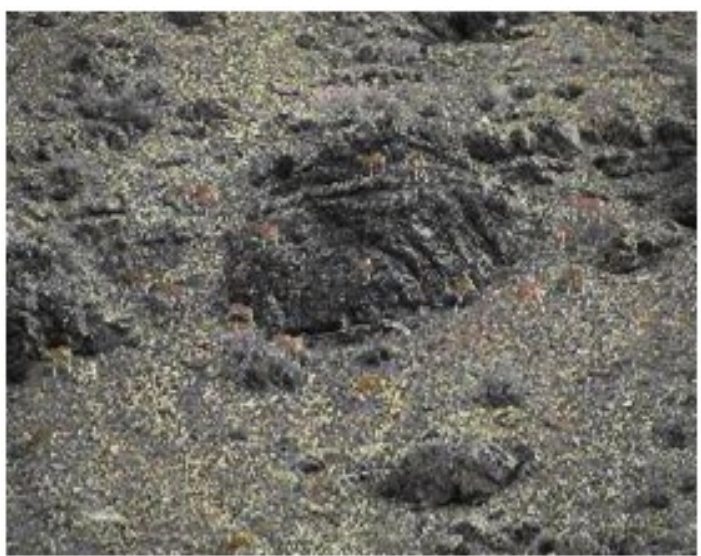

Fig. 8: antelope herd of Meygun highlands
Due to the Height, amount and type of precipitation is different from other regions. In the north, precipitation is mostly snow which remains on foothills for 9 months. After the end of the cold season, snow starts to melt from low to high amplitude (Figure 4) and melts completely by August. Some of the water from melting snow penetrates into the foothill as underground storage. Some others flow on the slopes and then flow into the hydrographic network.

However, other parts of the mountain have been directly affected by streams during the cold season. Simultaneous to gradual melting of snow and penetrating into the ground, the cold allows its re-freezing in rock gaps and thin surface layers (Figure 5). Mechanical weathering is the other simultaneous factor to deform heights.

Mountains are west-east following the general trend of Alborz. Entry into the area starts from Meygoon in the southeastern and continues to Dizin at an altitude of 4100 meters in the North West. Slope decreases from the North West to South East. In the first stage, orogenic movements formed current Alborz (Figure 6).

The fractured angled rocks indicate physical erosion caused by glaciation. Varnished rocks which shine in the sun indicate that they were carried by ice tabs. The three terraces on the western slopes of Tale-tange Valley indicate reduced temperature. Genesis and evolution of terraces can be a result of heavy rains that have been associated with later

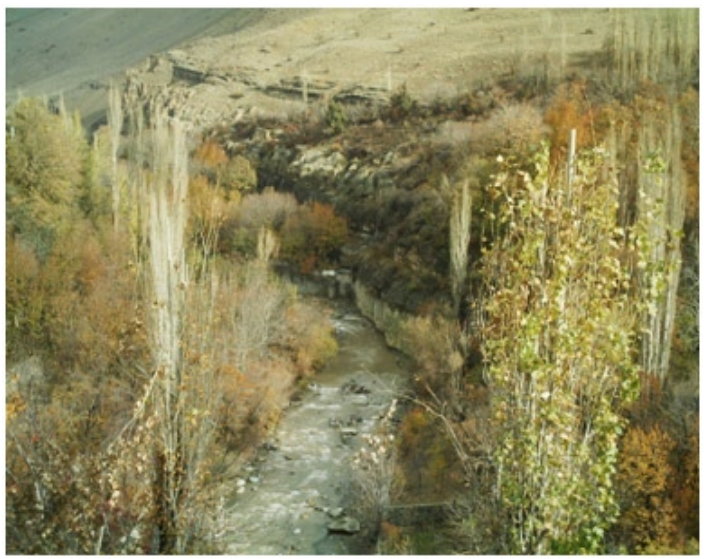

Fig. 9: foothills of Meygun; photo by author, 2008 

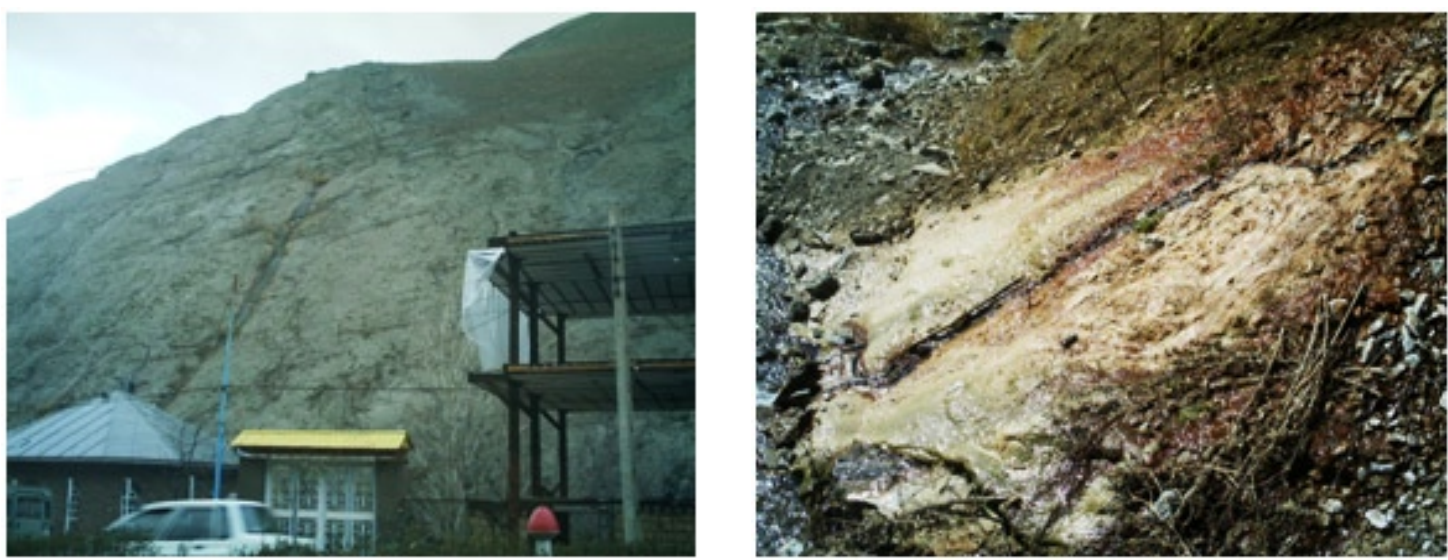

Fig. 10: right: sour-water Tale-Tange Spring; left: lime spring of north Meygun; photo by author, 2008

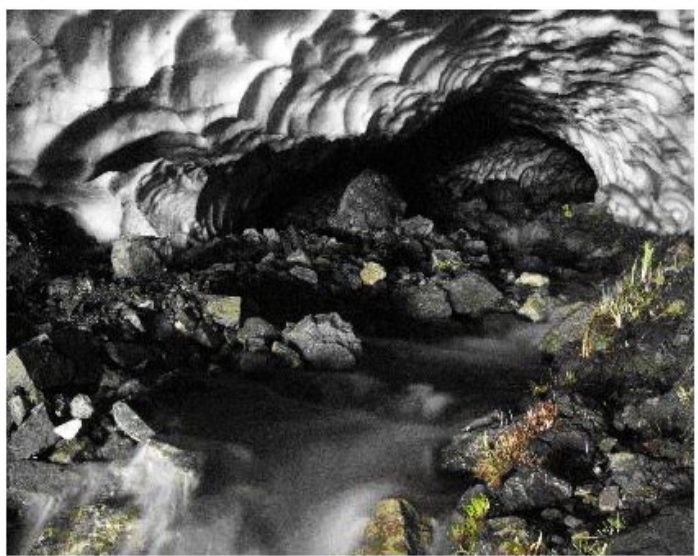

Fig. 11: snow tunnel of the Tale-Tange valley; photo by author, 2008

glacial stages. Mountains of the area attract many Climbers from all over the country. Climbing tours are held in all seasons.

This section is located in the middle Central Alborz. Mountain ranges surrounded the area as a belt. Abak Mountain (3488) is a rock anticline in the East of the basin and South of the Shemshak ski resort. There are Pey Tosum Mountain inside the resort from east (3350m), Mian Lalun (3420m) from north and northern east, Large Koloon Bastak (4150) and Small koloon Bastak (4100m) from north and Sichal $(3719 \mathrm{~m})$ from West. The Bareh Char Mountains $(3614 \mathrm{~m})$ is located in the west of Shemshak and Geirud. There are Ahangarak (3357m), Starchal and Hamloon mountains between Sichal and Meygun.
Hamloon Strait is located between Geirud and Meygoon, $35^{\circ} 59^{\prime}$ latitude and $51^{\circ} 28^{\prime}$ longitude at an altitude of 2311 meters. In this strait, there are remains of a cave called as Asbool by inhabitants. The valley is about $4 \mathrm{~km}$ in length and 50 meters in width. There are many fountains in the area (Figure 7).

Hamloon Mountains are made of Ruteh limestone in the lower parts; the thin limestone sediments and basic chromium are seen in west and east sides of the mountain. Hamloon cave is the result of dissolved Ruteh limestone in water penetrating the higher levels (Mehrpouya, 2000).

In different seasons even in winter, snow and ice-covered rock walls attract rock climbing and ice climbing sports enthusiasts to the region, which is the other factor to attract tourism.

Due to the weather (cold to temperate), there are Astragalus, Artemisia, Allium, Blackberry, sumac, Rosa canina, Alhagi, Rheum, and Hypericum perforatum in pastures of the area. At heights of Meygun, antelope herds can be seen in the pastures (figure 8).

Because of sandy and clay soils with good drainage, and abundant springs as well as Geirud and Shemshak rivers, crops and gardens can be seen in some places. The crops include wheat, alfalfa, and vegetables. Fruit tree in most valleys include cherry, fig, strawberry, apple, apricot, pomegranate and Greengage. 
In some tourist spots, there are species such as Tabriz cedar, Spruce, Willow, ailanthus, acacia and sycamore that are partly grown by man (Figure 9).

There are 13 springs in the studied area, of which 7 springs are located in the eastern north, 4 springs in the Quaternary sediments and 3 springs in Shemshak sediments; these springs indicate Permeability of the rocks. There is one spring in Bare Char Mountains in the west and three parallel springs in the foothills of Abnik Mountain in eastern north Meygun which is close to basin outlet (Figure 10). There is a bitter-water spring in the north Shemshak; the bitter taste is due to minerals in the rocks.

In the cold season, which begins in late November, precipitation is often in the form of snow. This snow accumulates and sometimes remains until late June. On the shallow valleys, sometimes snow accumulation covers the valley with snows from avalanche. The river continues to flow at the surface and creates a cave under snow accumulations, which is a beautiful phenomenon (Figure 11)

\section{CONCLUSIONS}

Because of its favourable climatic conditions and the presence of geomorphological phenomena such as glacial cirques, wandering rocks, waterfalls, and numerous fountains can be a good platform for further research and the introduction of the area as Jajrud basin geopark. Evidence of glacier indicates glacier period in this region; therefore, this region can be called a paleoclimatic geosite. Given the extent of constructions, it can be predicted that the area will become one of Tehran's major tourist hub in the future. Existence of favourable weather and ski resorts of Dizin and Shemshak attract many tourists to the area. Therefore, a proper policy can make the region one of the main tourist hub of Tehran.

\section{REFERENCES}

1. Abedi, I., Geotourism. www.parsgeotourism. com (2012)

2. Ghazi, I. \& Ghadiri, N., Evaluation of Geotourist Capabilities of National Desert Park Using New Strategic Planning Model. Ecology (2011).

3. Hamedi, M. \& Rezvani, A. A., Environment Role of Garden Cities in Attracting tourist and Developing Tourism; Case Study: Abhar. Geography (2012).

4. Maleki Orsi, S. \& Najaf Zadeh, Uch Tape Geosite in the Suggested Aras Geopark. s.I.,
S.n (2012).

5. Nekoui Sadri, B., Geotourism; Focusing on Iran. s.I.:Samt (2009).

6. Nojavan, M. R., Amir Hoseyni, A. \& Ramesht, M. H., Geotopes of Yazd and Its Attractions. Geography and Development (2009).

7. Papoli Yazdi, M. \& Saqaei, M., Tourism; Nature and Concepts. s.I.:Samt (2006).

8. Salimian, H., n.d. Geopark. www.geographyclass.blogfa.com

9. Zandi, E., an Introduction (2010). 